h lower than when the solution of the double salt was was plainly due to loss of gaseous hydrocarbons. ndard method proposed by the author he weighs ur grams of steel into a porcelain boat and covers h a layer of powdered fused lead chromate. The into a porcelain tube and heated to a white heat constructed combustion furnace provided with From thirty to forty minutes are required to comination. A few of the more important determinafollowing :

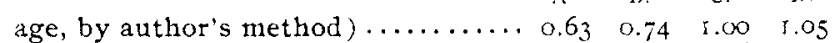
$\begin{array}{lllllll}\text { vinum, by double chloride method) } & . & 0.63 & 0.72 & 0.96 & 0.99\end{array}$

determination of carbon in chrome steel, ferro-chrome nganese the method seems to give higher and probably irustworthy figures than the methods heretofore used.

in his work with the double chloride of copper and ammonium slution the author seems to have failed to profit by the work of the American committee on international standards. If his double chloride solutions had been absolutely free from carbonaceous matter and had been strongly acidified with hydrochloric acid as the committee found essential, it is probable that the results would have agreed closely with those obtained by his ingeniously devised direct combustion method.

\title{
GERMAN ECONOMY IN IRON MANUFACTURE.
}

By Frank H. Mason, Consli-General.

$T$ has been recently noted in England with something like 1 alarm that the production and export trade of iron and steel in Germany have been steadily growing during the past ten years at a rate out of all proportion to the development of Great Britain in the same field, and that railway wheels, ties, axles, wire, etc., of German origin are not otlly making serious inroads upon foreign markets which British exporters have hitherto almost exclusively controlled, but are now sold to some extent in England. The fact that, in spite of all advantages which English ironmasters derive from long experience, cheap and abundant

1 Consular Reports, No. I55, August, 1893. 
coal, and unequaled shipping facilities, they are now undersold on their own ground by their German rivals would seem incredible if it were not sustained by actual statistics; and it may be of interest to American metal workers to examine briefly the more obvious causes of the notable progress of Germany in this important branch of industry.

It is conceded that until about $\mathrm{r} 880$ the British export trade in iron and steel was all that could be reasonably desired. Not only in respect to coal and skilled labor, but in facilities for importing ores from Spain, Scandinavia, and other foreign sources and for exporting their product, the English and Welsh furnace men seemed to have a secure advantage over their continental rivals. But it is now found that English exports of railway iron and steel have fallen from $1,000,000$ tons per annum a few years ago to 703,370 tons in 1891 and 467,986 tons in 1892 , while German exports of the same products, which had scarcely begun in 1880 , have risen to 198,421 tons in 1890 and 233,943 tons in I89 I, with a total export of pig and finished iron and steel amounting to a yearly average of $1,050,000$ tons. Not only this, but, in spite of the increased cost of coal in Germany, due to higher wages demanded by miners and the steadily increasing coal consumption in face of a definitely limited supply, the metal production of Germany has continued to increase. The proportions of this growth will be apparent when, with the fact in mind that in I 870 the total output of Germany was only 886,000 tons of iron and 125,000 tons of steel, we consider the following statistics of finished iron and steel manufacture in this country during the past two years:

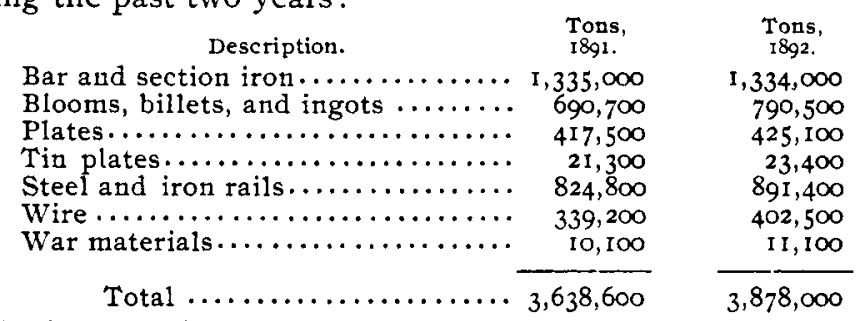

The increase in 1892 , it will be seen, was 239,400 tons.

Comparing the growth of iron and steel production in Great Britain and Germany from 1880 to 1892 , inclusive, it appears 
that, whercas England shows in increase of mly serenty per cent. Germany has achieved during the same period a net growth of nearly or quite foo per cent.

A result as striking as this must he the outgrowth of causes so radical as to be interesting to all who are concerned, either theoretically or commercially, in the metallurgy of steel and iron. The growing importance of (cermany in this field wonld seem to be due largely to two fundanental facts: (1) The introduction of the basic process. which enables the iron and steel makers of Westphalia, Silesia, and the Saarbriick district to use their cheap and abundant native nres: and (p) the unrivalus chemical shill of the Cremans whereby they have succected in saving the by-products of coke manulacture. thus deriving a rerenue from processes which in other comntries entail a waste of material and financial loss.

THI: BASIC PROCESS.

(If the basic process itself there is little or nothing new to be saich. It is understood as fully and practiced as successfully in the Lnited States as in any part of tine world. But its introduction into Germany has revolutionized the whole economy of steel manufacture in this country. With fair facilities for importing the richer ores of Spain and sweden, the German furnace men found their whole list of natre ores arailable, and when special processes were necessary to facilitate the employment of materials which had previously been considered worthless, they were invented and appliech. In a previous report of this series (No. I37, p. 246 ) an account was given of a special process for the clesulphuration of raw iron from the blast furnace by treatment with manganese, as invented and first practiced in direct steel production at Hurde. in Westphalia. This process. which has since been adopted at various other points on the Continent and in England, secures the production of excellent steel from materials so heavily charged with sulphur as to be impracticable for that purpose by ordinary methods.

ECONOMY OF BY-FROULCTS OF COKF.

Equally original and not less important to the general economy of iron manufacture are the more recent German improvements in coke making, by which the subsidiary products-ammonia, 
tar, and tar oils, with their valuable elements benzene, anthracene, etc.-are saved from the waste that attends the ordinary coking process. In this special field Germany is now so far in advance of other countries that some understanding of the methods employed here is important in the present connection.

The first record of any practical interest in the saving of ammonia and tar from the coking process appears in a paper which was read before a convention of ironmasters at Dusseldorf by one $\mathrm{F}$. W. Lurman in 1858 . The main principles involved were clearly stated, but the requisite apparatus was so elaborate and expensive and the financial results then so doubtful that progress was for a long time slow and uncertain. The improved methods now in use, and which have produced the best results, are mainly the work of the past five years. What is known as the Semet-Solvay system is the one principally in use in Belgium; but the most advanced representative of German progress in this direction is probably the Otto-Hoffman coke oven, of which there are about $I, 550$ now in use -535 in Westphalia, 700 in Silesia, seventy-five in the Saar district, and 240 in Austria. Although elaborate and costly in construction, this oven is durable and, by reason of its great saving in gas, highly economical in operation, aside from its efficiency in saving the subsidiary products. The complete apparatus is a combination of the Otto oven (thirty-two feet long, sixteen inches wide, and five and one-half feet high) with the Siemens regenerator in such manner that the air to be used for the combustion of gases is first heated to a temperature of about $1800^{\circ} \mathrm{F}$.

For the most economical service these ovens are built in groups or batteries of sixty, and half the number are alternately filled each forty-eight hours. The oven has three openings through which it is charged from above with six and one-half tons of air-dried coal. The openings being then tightlv closed, heat is applied, and the gases generated are drawn off tnrough collecting pipes by the action of a suction fan into coolers and scrubbers, where the tar and ammonia are deposited in water by mechanical distillation. The gas, thus purified of tar and ammonia, is then reconducted to the bottom of the ovens, where it is mingled with the heated air above mentioned and burned as 
fuel in the process of roasting the coal. The percentage of gas produced varies somewhat with the quality of coal used; but with all the German coals the gas thus generated is greatly in excess of what is required for heating the ovens, and the surplus is available for making steam, lighting, and for other purposes.

The water from the coolers and scrubhers, charged with the ammonia that has been absorbed from the gas, is subjected to heat, which expels the ammonia as vapor, which in presence of sulphuric acid forms sulphate of ammonia, a white salt that is extensively used for fertilizing purposes. The tar, by reason of its grarity, settles to the botton of the water and is easily separated. It is more valuable than the tar producer in the ordinary manufacture of illuminating gas, on acconnt of its greater percentage of benzene and anthracene. For a long time there prevailed among German irommasters a notion that coke produced by any process that saved the by-products was thereby injured for iron-making, but this is now completely dispelled. The coke made by the abore process is conceded to be of the lighest quality for all purposes.

The operation of coking requires in the Otto-Hoffman ovens from twenty-four to forty-eight hours; and the product from good air-dried coal containing from fifteen to seventeen per cent. of water is about seventy-six per cent. of coke, 1.15 to I.25 per cent. of sulphate of ammonia, and from 2.5 to 4 per cent. of tar. In a recent number of the Journal für Gasbelcuchtung und llasserwersorgung (Munich) the following résumé is given of the actual work of a battery of sixty ovens, operating with local coal in the three principal mining districts of Germany.

One ton of coal produces:

\begin{tabular}{|c|c|c|c|}
\hline District. & $\begin{array}{l}\text { Cone. } \\
\text { pounds. }\end{array}$ & $\begin{array}{c}\text { Tar. } \\
\text { Younds. }\end{array}$ & $\begin{array}{l}\text { Suiphate of } \\
\text { ammonia. } \\
\text { Pounds. }\end{array}$ \\
\hline Ruhr $\ldots \ldots \ldots \ldots \ldots \ldots$ & 1,672 & 60.5 & $25 \cdot 3$ \\
\hline 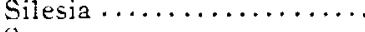 & 1,496 & $93 \cdot 5$ & 26.4 \\
\hline aat & 5,540 & 91.3 & 18.7 \\
\hline
\end{tabular}

The yearly product of sixty ovens is :

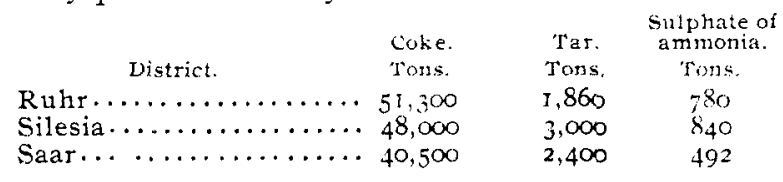


The generation, consumption, and surplus of gas for one oven per day are as follows:

\begin{tabular}{|c|c|c|c|}
\hline District. & $\begin{array}{l}\text { Production. } \\
\text { Cubic feet. }\end{array}$ & $\begin{array}{l}\text { Consumption. } \\
\text { Cubic feet. }\end{array}$ & $\begin{array}{l}\text { Surplus. } \\
\text { Cubic feet. }\end{array}$ \\
\hline & - 32,000 & 19,200 & 12,800 \\
\hline & - $3^{6,800}$ & 20,800 & $16, \infty 00$ \\
\hline . & - 32,000 & 19,200 & 12,800 \\
\hline
\end{tabular}

So that a battery of sixty ovens, working under the above conditions, would furnish gas for their own heating and yield a surplus of from 76,000 to 96,000 cubic feet per day to be used for other purposes. It is reckoned in practice that 100 cubic meters $(3,200$ cubic feet) of this surplus coke gas is equivalent, for purposes of heating, to 87.5 kilograms (193.5 pounds) of coal; and the saving of fuel in working sixty coke ovens would therefore be :

\begin{tabular}{|c|c|c|}
\hline District. & $\begin{array}{l}\text { Per day. } \\
\text { Kilograms. }\end{array}$ & $\begin{array}{l}\text { Per year. } \\
\text { Tons. }\end{array}$ \\
\hline Ruhr........ & - $21, \infty 00$ & 7,560 \\
\hline 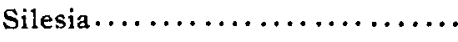 & .. 26,250 & $9,45^{\circ}$ \\
\hline 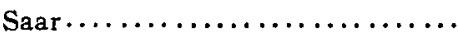 & . $21, \infty 00$ & 7,560 \\
\hline
\end{tabular}

But, since the Otto-Hoffman oven involves, also, the use of the other appliances which require heat to the extent of onethird the amount saved in the form of gas, it follows that the actual economy in fuel is about two-thirds of the above totals expressed in coal. Add to this saving of coal the two byproducts-sulphate of ammonia, worth in the market $\$ 5.23$ per roo kilograms (220 pounds), and tar, worth about ninety-five cents per 100 kilograms-and the enormous profits which are claimed for this system do not appear incredible.

From another, but trustworthy, source it is announced that the revenue actually derived from the tar and ammonia produced by one year's working of a group of sixty ovens in Westphalia, which cost in construction $\$ 166,000$ (or $\$ 2,766$ each), was $\$ 40,200$, or about twenty-five per cent. on the capital invested in the plant. The price given above does not include the cost of condensing apparatus, which, although it is not a part of the oven, is worked in connection with it.

It should not be understood from the foregoing that the OttoHoffman is the only highly improved coke oven in Germany which saves the secondary products. There are, in fact, several others 
of later construction for which their inventors claim certain points of superiority over the Otto, but the latter has been longest in use and is therefore the best known. From the known aggregate product of tar and anumonia in this conntry, it is calculated that there are at present in operation in the country not less than 3,000 coke ovens which save the subsidiary products, so that the 5,550 Otto ovens in operation are something more than half the entire number of all kinds in actual use.

A comparison of the results obtained by the Semet-Solvay system in Belgium with those realized by the best German orens shows a clear advantage in favor of the latter. In the Semet orens an intense degree of heat is generated, so that it is not found necessary to combine them with regenerators to heat the air which is to be used in combustion. They are therefore considerably cheaper in construction; but, on the other hand, the Semet requires for good results a special mixture of "fat" and "lean" coal that is not always easy to provide, and, while the coke thus made is of a high and uniform quality, it produces much less anmonia, tar, and gas than the best German ovens, and is therefore in the end less profitable.

The direct production of benzene in the coking process is difficult, but it has been successfully accomplished during the past year by an inventor at Dortmund, whose process is thus far a secret. So far as can be ascertained, from six and one-half to fifteen pounds of benzene are obtained from a ton of dry coal; and, as benzene is an important element in anilin manufacture, it may be ranked among the products that will always have a standard value. The effect of the 3,000 improved coke ovens now in use in Germany and Austria has been to greatly increase the supply and reduce the market values of the by-products which they secure. Sulphate of ammonia, which, besides its uses as a fertilizer, is largely employed in making ice and in soda manufacture, was in 1883 worth $\$ 7.37$ per loo kilograms, but now sells for about $\$ 5.25$; and tar has declined from $\$ 1.30$ per roo kilograms to ninety-five cents in the same period. Notwithstanding this decline, the profits derived from these two subsidiary products of coke manufacture are stated by good authorities to be as high as forty per cent., all of which goes to 
the credit side in the general account of Germany's mining and metal industries.

But this is not all. Still another point in which the Germans secure an important advantage, especially as respects their American competitors, is in economizing the waste and coarser forms of fuel. It is conceded that Americans are masters of economy in labor, but they are extravagant with materials. In our country millions of tons of coal dust-the waste of mines, railways, and iron mills-are thrown away as useless. An official commission, after exhaustive study of the subject, has recently published the astounding information that for every ton of anthracite coal mined and marketed in Pennsylvania, one and one-half tons are wasted; and the loss in bituminous coal, although somewhat less, is still enormous. In Germany, France, and Belgium all this refuse coal dust is carefully saved. Part of it is mixed with pitch derived from tar distillation and molded into "bricquettes," which are used as fuel for locomotives, stationary engines, and household grates. The remainder of this finely pulverized carbon is blown by jets of live steam into various kinds of furnaces, where it burns with almost the fierceness of crude petroleum. Coal dust from mines costs in Germany twenty-five cents per ton on cars, or in large quantities $\$ 2.3^{8}$ per carload of ten tons, and the care with which it is saved and utilized adds an important percentage to the fuel supply of this country. It is by this application of scientific economy to every stage of manufacture, the saving of secondary products, and the invention of new processes and machinery to work most advantageously native materials that the German iron and steel makers have been able to face without disaster the declining metal markets of the past four years.

The question may be fairly asked whether the time has not come for Americans to study far more carefully than they have studied hitherto the scientific economies of manufacture. Europeans stand aghast at the recklessness with which our forests and mines and petroleum deposits are being exhausted and the soil of vast acres drained of its fertility by forms of culture which wring a yearly crop from the land, but give back little or nothing in return. There are in nearly every coal-mining dis- 
trict in the United States great mounds and embankments of discarded slack and coal dust which, under a better system, might be utilized as fuel; and fortunes are lost every year in the clouds of gas and smoke that rise from the coke ovens of Virginia, Pennsylvania, Ohio, and Alabama. With soda, salt, and phosphate beds in a dozen states, we import the heavy chemicals for soap and paper making and annually purchase from Europe sulphuric acids and chemical fertilizers which ought to be made at home. There is a lesson in the coke ovens and chemical laboratories of France and Germany which the economists and manufacturers of America can not study too thoroughly nor too soon.

\section{NEW BOOKS.}

Researches UPON THE PheNOMENA OF OXIDATION AND Chemical Properties of Gases. By Francis C. Phillips. ${ }^{1}$

The dissertation, which is reprinted from the Transactions of the American Philosophical Society, 17, May 26, I893, is published in two parts, the first of which deals with:

(a) Phenomena of Oxidation of Hydrogen, Carbonic Oxide, Gaseous Paraffins, Olefines, and Acetylene.

(b) Qualitative Reactions of Gases.

(c) Substitution Products of the Action of Chlorine Upon Methane.

(d) Preparation of Halogen Compounds of Alkyls and Olefines.

In (a) the author has directed his experiments chiefly towards ascertaining the temperatures at which combustible gases, when mixed with air and passed over asbestos impregnated with various metals, will unite with oxygen. Asbestos fiber was coated with the different metals by moistening the asbestos with a solution of the chloride of the metal and then dropping alcohol on the fiber and igniting it: The metals employed were palladium, gold, platinum, iridium, osmium, rhodium, and palladium-platinum. About 0.3 gram of the asbestos thus prepared

I Dissertation for the degree of Doctor of Philosophy, Cniversity of Pennsylvania. 